https://doi.org/10.15407/geotech2019.29.032

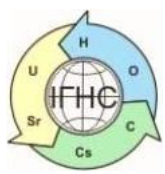

УДК 622.25: 502.36/55

\title{
Буглак О.В.
}

Буглак О.В., м.н.с., Державна екологічна академія післядипломної освіти та управління, Київ, aleksandra.verkhovtseva@ gmail.com

\section{ТЕХНОГЕННЕ ЗАБРУДНЕННЯ АТМОСФЕРИ ВНАСЛІДОК ФУНКЦІОНУВАННЯ І ЗАКРИТТЯ ВУГІЛЬНИХ ШАХТ ТА ЗАХОДИ ЩОДО ЙОГО ЗАПОБІГАННЮ (МІНІ- МІЗАЦІї)}

Видобуток вугілля призводить до змін оточуючого ландшафту за рахунок нагромадження гірничих мас. Шахтні породи в териконах схильні до самозагоряння, щзо призводить до хімічного забруднення атмосфери продуктами горіння. Розглянуто види порушень навколишнього середовища, їх причини (зокрема, викиди отруйних речовин промисловими підприємствами регіону, викиди парникових газів та твердих часточок (сажа) із димарів, випаровування летких отруйних речовин із відстійників, пилове забруднення - здування отруйних речовин із золо-, шлако- і шламовідвалів, териконів, забруднення атмосферного повітря викидами від стаціонарних та пересувних джерел - золою від теплоелектростанцій, формальдегідами, діоксидом азоту та ін., транскордонне перенесення забруднювальних речовин повітрям у прикордонних областях, тощо) та наслідки, щз зумовлюють забруднення атмосферного повітря. Встановлено основні проблеми охорони атмосферного повітря, до яких належать виявлення фактичних викидів шкідливих речовин в атмосферу за технологічними циклами об'єктами шахтного комплексу і вугільними підприємствами у ичілому, проведення їх кількісної і якісної оцінки. Проаналізовано та графічно проілюстровано дані шзодо забруднення атмосферного повітря вугільними підприємствами Украӥни за 2018 рік. У якості природоохоронних заходів шуодо атмосферного повітря пропонується та передбачається: проведення робіт із гасіння породних відвалів, щзо горять; застосування екологічно чистих і безпечних технологій формування нових породних відвалів; виконання профілактичних робіт із запобігання самозаймання відвалів; оснашення організованих джерел викидів новими газоочисними установками, аспіраційними системами, золоуловлювачами, електрофільтрами; реконструкція котлоагрегатів котелень тошо..

Ключові слова:вугільна шахта, довкілля, техногенне забруднення, атмосферне повітря, еколого-технічні показники, природоохоронні заходи, база даних

Вступ

Вугільна промисловість України є базовою галуззю промисловості з досить складними технологічними процесами, що зумовлює значний вплив на навколишнє природне середовище.

Територіально вугледобувні та переробні підприємства галузі розміщені у восьми областях України. Характерною особливістю їх розміщення $є$ нерівномірність, часто надмірна концентрація виробництва в окремих районах вугледобувних регіонів.

Виробнича діяльність вугледобувної промисловості супроводжується як залученням в розробку нових площ діючих родовищ, так і закриттям відпрацьованих або нерентабельних вугільних шахт. За своєю сукупністю перераховані вище особливості в поєднанні з високою концентрацією вуглевидобувних i переробних підприємств визначають довготривалий техногенний вплив на зміну стану і властивостей як геологічного, так і навколишнього природного середовища в цілому, і не тільки на локальних ділянках окремих родовищ, але і в регіональному плані.
Технологічні процеси вуглевидобутку, збагачення та використання, зокрема, спалювання вугілля, супроводжуються утворенням і виділенням значної кількості пилу і газів. Це призводить не тільки до локального забруднення атмосфери, але і до таких глобальних негативних процесів, як парниковий ефект, порушення озонового шару, окислення атмосферних опадів та ін. Підприємствами вугільної промисловості здійснюються викиди в атмосферне повітря, головним чином, пилу, парникових (окису $\mathrm{CO}$ і двоокису вуглецю $\mathrm{CO}_{2}$, метану $\mathrm{CH}_{4}$ i частково $\mathrm{NO}_{2}$ ) і кислотних газів (двоокису сірки $\mathrm{SO}_{2}$ і оксидів азоту $\mathrm{NO}_{\mathrm{x}}$ ). Головними джерелами забруднення атмосфери зазначеними газами і пилом у вугільній промисловості $є$ шахти, збагачувальні фабрики, котельні, ТЕЦ, палаючі породні відвали та ін. [1-12].

Основні результати дослідження. Сучасні проблеми екологічного стану навколишнього природного середовища навколо вугільних шахт України стосуються порушення екосистем та природноландшафтних територій, руйнування промислових та 
екологічно небезпечних об'єктів, забруднення джерел питної води, земель, атмосферного повітря, порушення геологічного середовища.

Всі вугільні басейни знаходяться на тому етапі розвитку, коли обсяги видобутку вугілля зменшуються, значна кількість шахт припиняє розробку запасів вугілля, а згодом ці шахти ліквідуються. Зазначені обставини призвели до суттєвої зміни в межах басейнів більш-менш усталених природно-техногенних умов, які сформувались у результаті впливу на природні компоненти розробки вугільних родовищ [2, 3, 5-12]. Вимоги чинного законодавства України (закони України «Про охорону навколишнього природного середовища», «Про охорону атмосферного повітря», «Про відходи», «Водний кодекс України», «Кодекс України «Про надра», «Земельний кодекс України», а також нормативні документи Міністерства екології та природних ресурсів України) обумовлюють необхідність розробки нових, більш дієвих заходів та концептуальних підходів до вирішення питань охорони навколишнього середовища у вугільних регіонах [13$18]$.

Атмосферне повітря - це життєво важливий компонент навколишнього природного середовища, який являє собою природну суміш газів, що перебуває за межами житлових, виробничих та інших приміщень.

\section{Причини забруднення атмосфери:}

- викиди отруйних речовин промисловими підприємствами (міста Маріуполь і Горлівка Донецької області - своєрідні «рекордсмени» України за вмістом шкідливих речовин у повітрі: формальдегід, діоксид азоту, фенол, бенз(а)пірен, фтороводень, оксид вуглецю, завислі речовини);

- викиди парникових газів та викиди твердих часточок (сажа) із димарів;

- випаровування летких отруйних речовин із відстійників;

- пилове забруднення (здування отруйних речовин із золо-, шлако- і шламовідвалів, териконів);

- $\quad$ забруднення атмосферного повітря викидами від стаціонарних та пересувних джерел (золою від ТЕЦ, формальдегідами, діоксидом азоту та ін.) на тлі падіння обсягів промислового виробництва;

- катастрофічна ситуація із загазованістю міст, де технологічне обладнання не оновлювалося протягом тривалого періоду (кількість обладнання 3 терміном експлуатації 40 років і більше перевищує $70 \%)$
- забруднення повітря внаслідок діяльності підприємств нафтогазового комплексу та під час спалювання газу у факелах;

- транскордонне перенесення забруднювальних речовин повітрям у прикордонних областях (практично неконтрольований процес через відсутність достатньої кількості мобільних і стаціонарних пунктів спостереження).

\section{Основні проблеми охорони атмосферного повітря:}

- виявлення фактичних викидів шкідливих речовин в атмосферу за технологічними циклами, об’єктами шахтного комплексу і підприємствами у цілому, проведення їх кількісної та якісної оцінки;

- визначення пріоритетних напрямів для проведення комплексних робіт зі зниження рівня шкідливих викидів;

- $\quad$ впровадження нових технологій використання шахтного газу дегазаційних і вентиляційних установок.

- $\quad$ інтенсифікація робіт з переформування і гасіння та рекультивації породних відвалів;

- $\quad$ створення системи моніторингу.

Аналіз отриманих у 2018 році від вугільних підприємств України даних щодо забруднення атмосферного повітря, здійснений при виконанні науково-дослідної роботи «Моніторинг виконання природоохоронних робіт та екологічного стану природного довкілля діючих та ліквідованих вугільних підприємств, розроблення пропозицій щодо його поліпшення» [1], показав наступне (зведена табл. 1 за I - IV кв. 2018 року).

$\begin{array}{ccc}\text { Загальна } & \text { кількість джерел } & \text { викидів } \\ \text { забруднюючих } & \text { речовин } & \text { складає }\end{array}$ 1356 одиниць (рис. 1), 3 них організованих - 518 одиниць, неорганізованих - 838 одиниці (рис. 2).Викиди забруднюючих речовин в атмосферне повітря вугільними підприємствами складають всього 274004.10 т/рік (рис. 3), а окремо за кожним державним підприємством показано на рис. 4.

Викиди в атмосферу парникових газів, у тому числі метану, показано на рис. 5.

Обсяг викидів парникових газів в атмосферу від стаціонарних установок протягом 2018 року представлено на рис. 6 та 7 (у \%). 


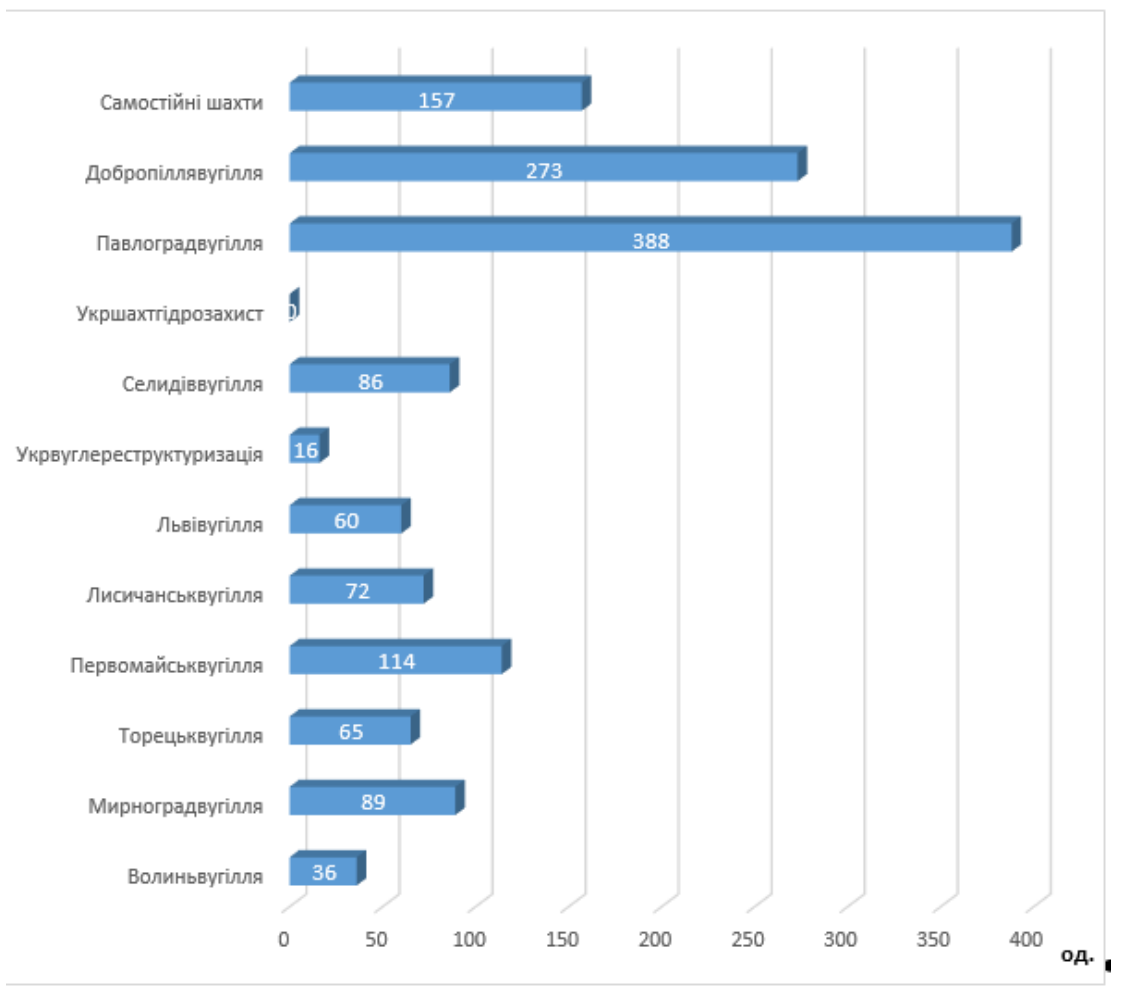

Рис. 1. Розподіл джерел викидів забруднюючих речовин за 2018 рік, всього (од). Fig. 1.Distribution of pollutant emission sources in 2018, total (unit).

од.

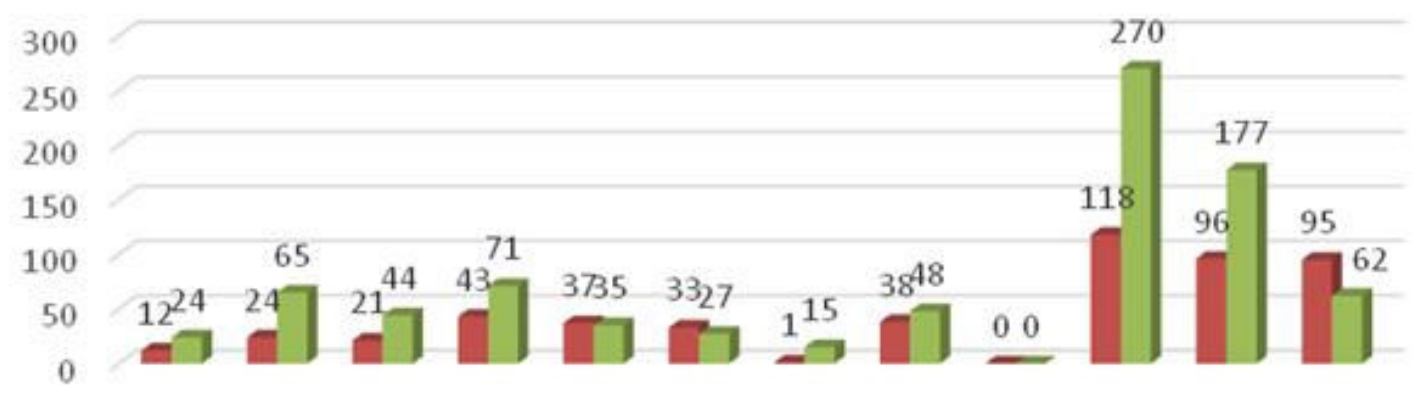

Кількість організованих джерел викидів 표 Кккість неорганізованихджерел викидів

Рис. 2. Розподіл організованих i неорганізованих джерел викидів забруднюючих речовин за 2018 p. 3 з підприсмствами (од).

Fig. 2.Distribution of organized and unorganized sources of pollutant emissions in 2018 by enterprises (units).

1-Волиньвугілля (12; 24 од.)

2-Мирноградвугілля (24; 65 од.)

3-Торецьквугілля (21; 44 од.)

4-Первомайськвугілля (43; 71 од.)

5-Лисичанськвугілля (37; 35 од.)

6-Львіввугілля (33; 27 од.)
7-Укрвуглереструктуризація (1; 15 од.)

8-Селідоввугілля (38; 48 од.)

9-Укршахтгідрозахист (0 од.)

10-Павлоградвугілля (118; 270 од.)

11-Добропіллявугілля (96; 177 од.)

12-Самостійні шахти (95; 62 од.) 


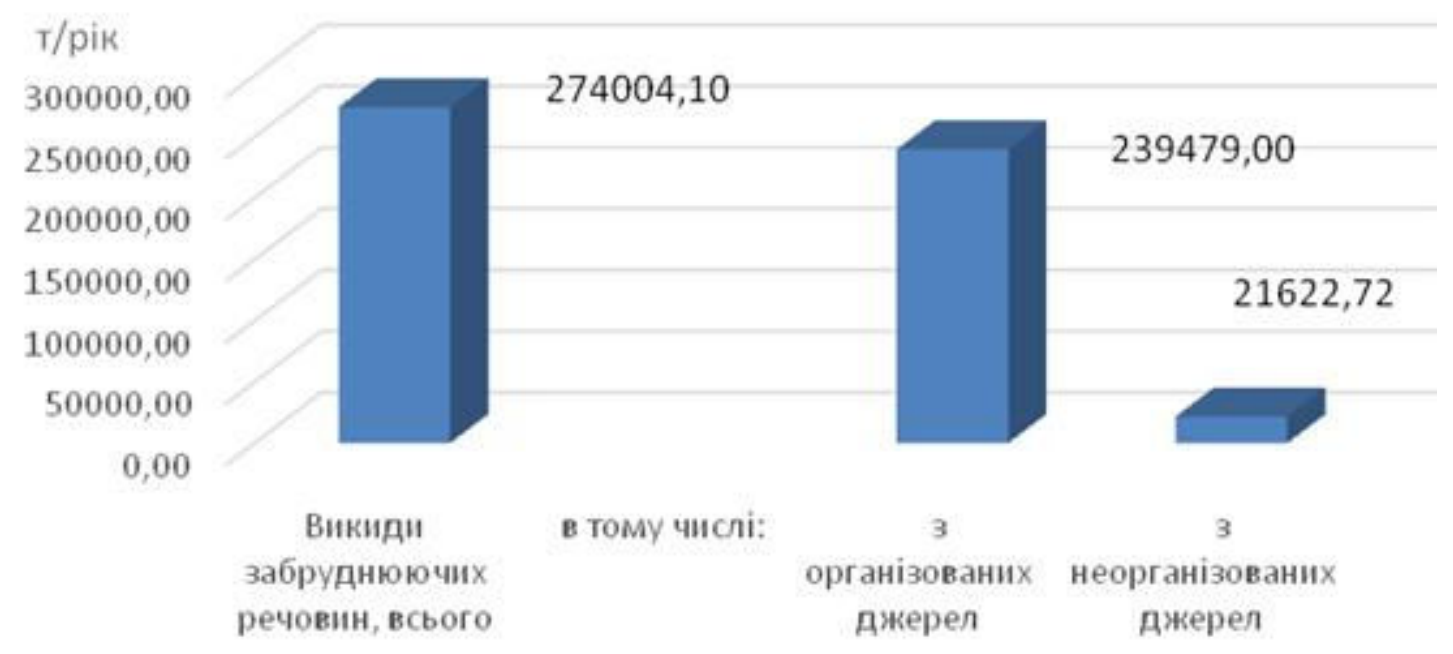

Рис. 3. Викиди забруднюючих речовин за 2018 рік, всього, (т/рік).

Fig. 3. Emissions of pollutants for 2018, total, (t/year).

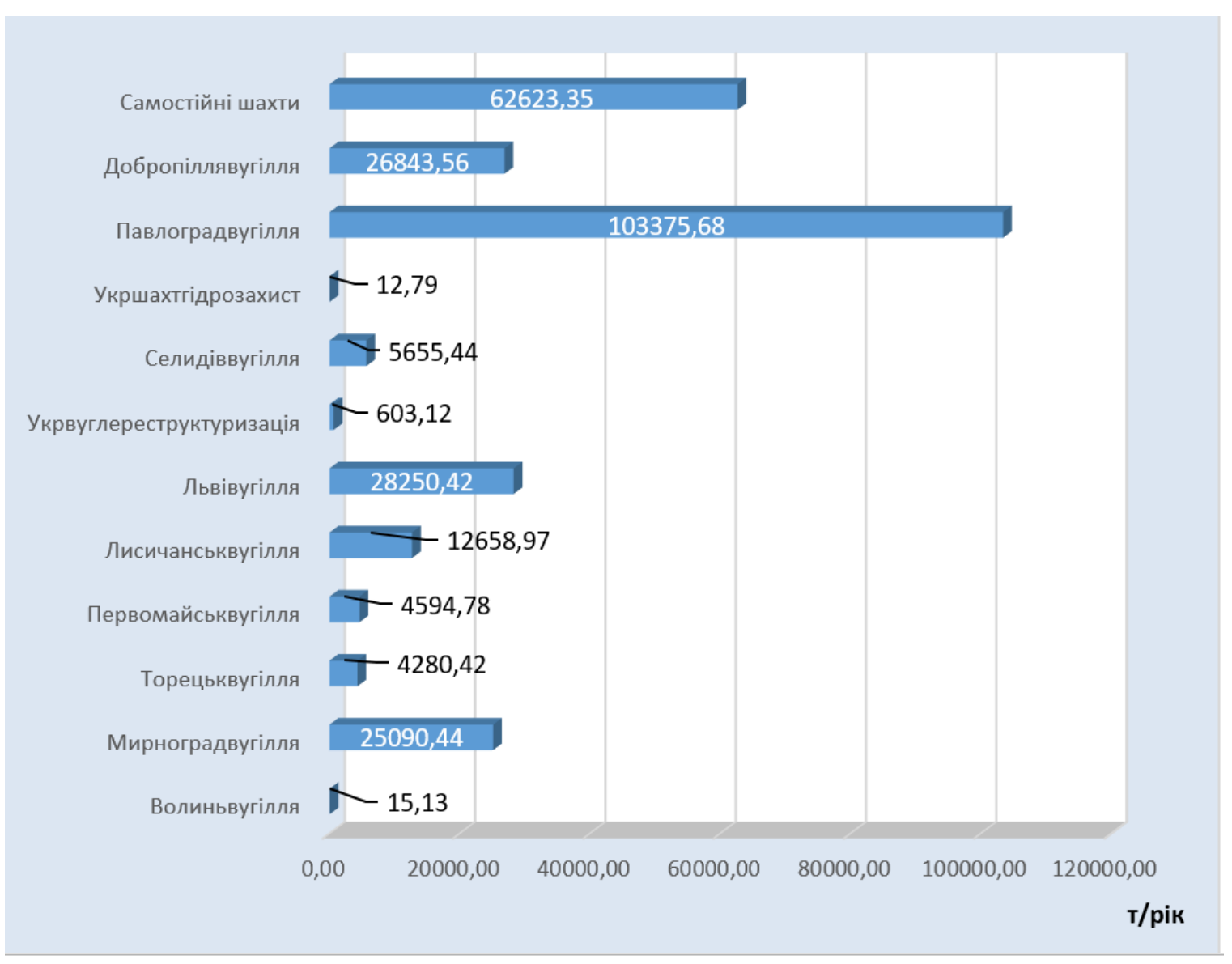

Рис. 4. Викиди забруднюючих речовин за підприємствами за 2018 рік, (т/рік).

Fig. 4.Emissions of pollutants by enterprises in 2018, (t/year). 


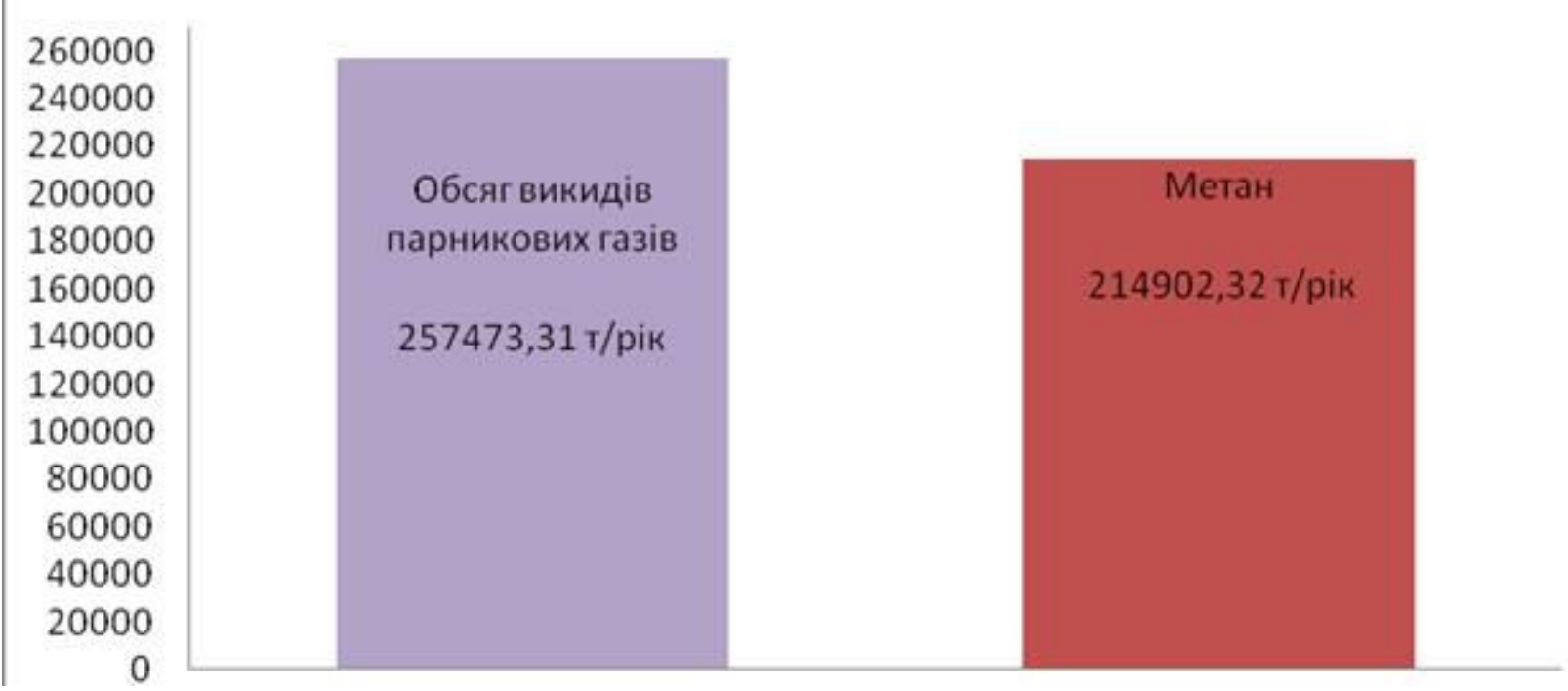

Рис. 5. Викиди в атмосферу парникових газів за 2018 рік, всього (т/рік).

Fig. 5. Emissions of greenhouse gases into the atmosphere in 2018, total (t/year)

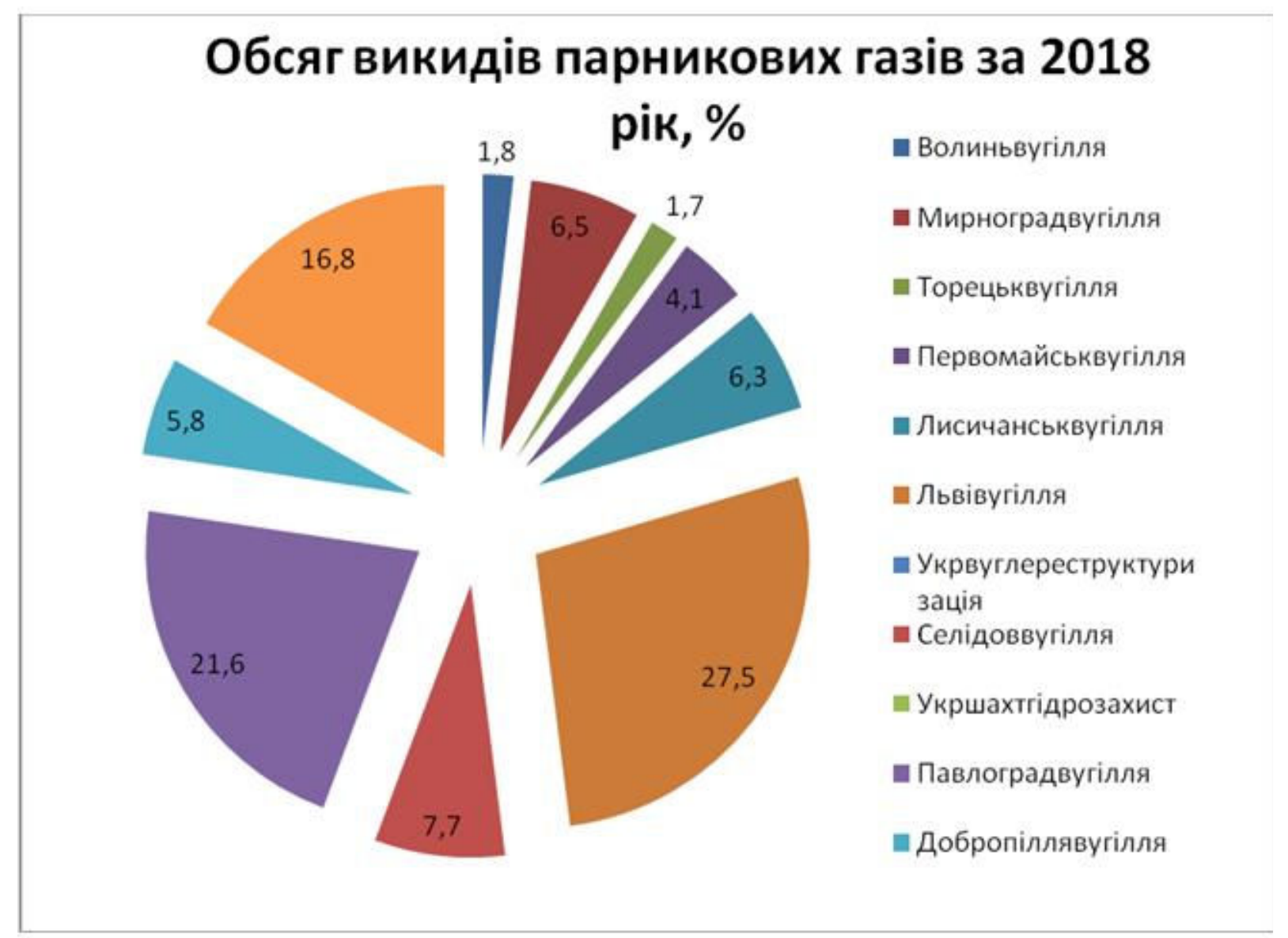

Рис. 6. Обсяг викидів парникових газів за 2018 рік, \%.

Fig. 6. The amount of greenhouse gas emissions in $2018, \%$.

1-Волиньвугілля $(1,8 \%)$

2-Мирноградвугілля $(6,5 \%)$

3-Торецьквугілля $(1,7 \%)$

4-Первомайськвугілля $(4,1 \%)$

5-Лисичанськвугілля $(6,3 \%)$

6-Львіввугілля $(27,5 \%)$
7-Укрвуглереструктуризація (0 \%)

8-Селідоввугілля $(7,7 \%)$

9-Укршахтгідрозахист (0 \%)

10-Павлоградвугілля $(21,6 \%)$

11-Добропіллявугілля $(5,8 \%)$

12-Самостійні шахти (16,8\%) 


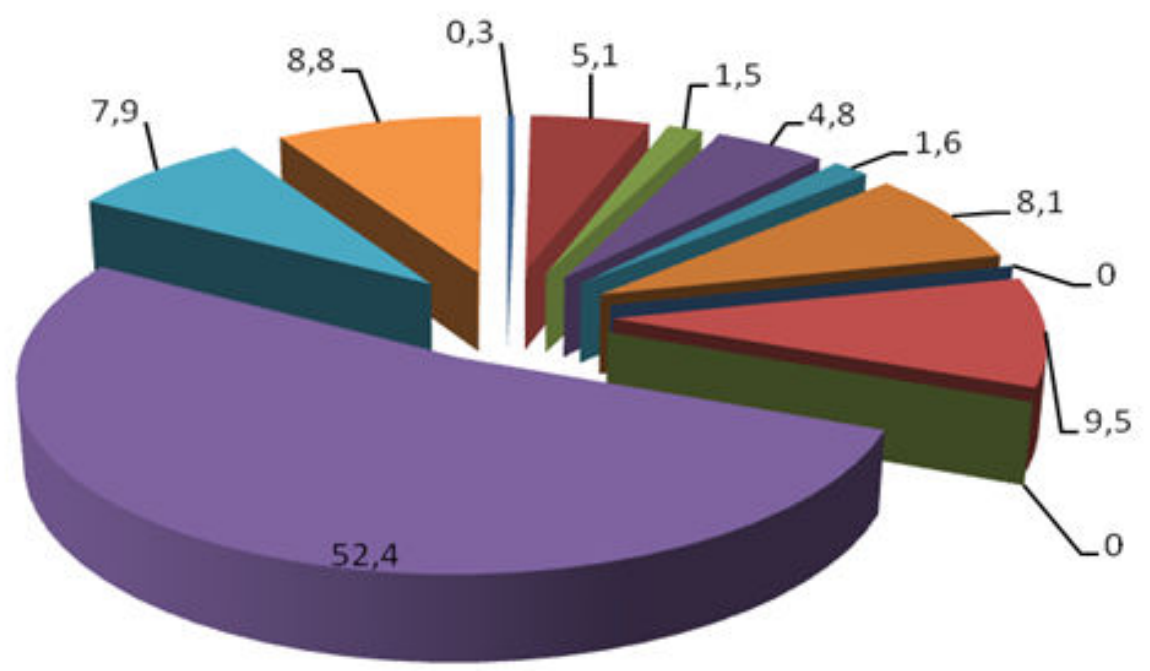

Волиньвугілля

Мирноградвугілля

Торецьквугілля

Первомайськвугілля

Лисичанськвугілля

львівугілля

- Укрвуглереструктуризація

- Селідоввугілля

Рис. 7. Викиди важких металів в атмосферу від стаціонарних установок протягом 2018 року, \% Fig.7. Emissions of heavy metals into the atmosphere from stationary installations du ring 2018, \%

\author{
1-Волиньвугілля $(0,3 \%)$ \\ 2-Мирноградвугілля $(5,1 \%)$ \\ 3-Торецьквугілля $(1,5 \%)$ \\ 4-Первомайськвугілля $(4,8 \%)$ \\ 5 -Лисичанськвугілля $(1,6 \%)$ \\ 6-Львівугілля $(8,1 \%)$
}

\author{
7-Укрвуглереструктуризація (0 \%) \\ 8-Селідоввугілля $(9,5 \%)$ \\ 9-Укршахтгідрозахист (0 \%) \\ 10 -Павлоградвугілля $(52,4 \%)$ \\ 11-Добропіллявугілля $(7,9 \%)$ \\ 12-Самостійні шахти $(8,8 \%)$
}

До узагальнених показників впливу вугільних підприємств на атмосферне повітря можна віднести:

- загальну кількість джерел викидів забруднюючих речовин, всього - 1356 одиниць, як і в 2017 році;

- викиди забруднюючих речовин в атмосферне повітря, всього за 2018 рік - 274004,10 т/рік, що на 16117,70 т/рік менше за показники 2017 року.

В якості природоохоронних заходів щиоо атмосферного повітряпропонусться та передбачасться:

- проведення робіт із гасіння породних відвалів, що горять;

- застосування екологічно чистих і безпечних технологій формування нових породних відвалів;

- виконання профілактичних робіт із запобігання самозаймання відвалів;

- оснащення організованих джерел викидів новими газоочисними установками, аспіраційними системами, золоуловлювачами, електрофільтрами; - реконструкція котлоагрегатів котелень

\section{Висновки}

ПроведенийДержавною екологічною академією післядипломної освіти та управління аналіз екологотехнічних показників діяльності вугільних підприємств є основою при вирішенні Міністерством енергетики та вугільної промисловості України проблем екологічного характеру - поліпшення умов проживання населення в районах розташування вугільних підприємств, зменшення сольового і механічного забруднення поверхневих вод та водойм від скидів в них шахтних вод, зменшення викидів забруднюючих речовин в атмосферу, раціональне використання природних і земельних ресурсів, підвищення ефективності природоохоронних заходів, що проводяться вугільними підприємствами.

При виконанні роботи було оновлено базу даних еколого-технічних показників вугільних підприємств за такими напрямами: атмосферне повітря, водні ресурси, земельні ресурси та охорона навколишнього природного середовища. тощо. 
Таблиця 1. Зведена таблиця отриманих даних від вугільних підприємств щодо забруднення атмосферного повітря за 2018 p Table 1. Summary table of the received data from coal enterprises on atmospheric air pollution in 2018

\begin{tabular}{|c|c|c|c|c|c|c|c|c|c|c|c|c|c|c|c|}
\hline \multirow[b]{2}{*}{$\begin{array}{l}\text { № } \\
\text { п/П }\end{array}$} & \multirow[b]{2}{*}{ Найменування показника } & \multirow[b]{2}{*}{ Од.виміру } & \multicolumn{12}{|c|}{ Мінвугле пром } & \multirow[b]{2}{*}{$\begin{array}{l}0 \\
0 \\
0 \\
0 \\
0\end{array}$} \\
\hline & & & 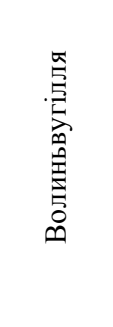 & 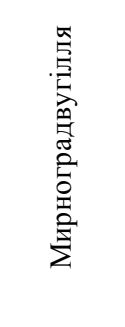 & 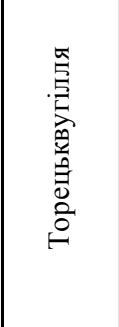 & 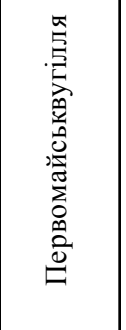 & 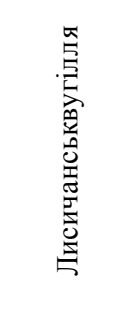 & 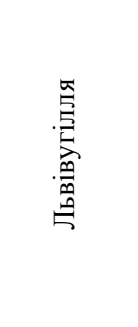 & 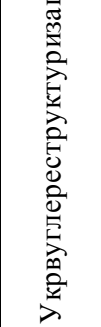 & 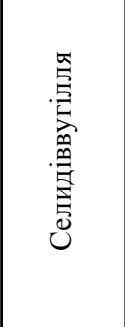 & 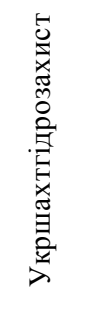 & 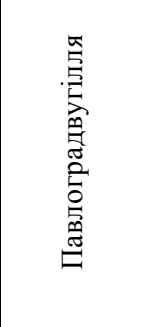 & 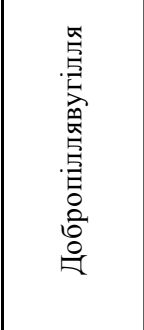 & 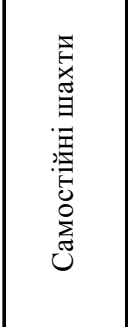 & \\
\hline 1 & $\begin{array}{l}\text { Загальна кількість джерел викидів } \\
\text { забруднюючих речовин, всього }\end{array}$ & од. & 36 & 89 & 65 & 114 & 72 & 60 & 16 & 86 & 0 & 388 & 273 & 157 & 1356 \\
\hline \begin{tabular}{|l|l|}
2 \\
\end{tabular} & Кількість організованих джерел викидів & од. & 12 & 24 & 21 & 43 & 37 & 33 & 1 & 38 & 0 & 118 & 96 & 95 & 518 \\
\hline 3 & Кількість неорганізованих джерел викидів & од. & 24 & 65 & 44 & 71 & 35 & 27 & 15 & 48 & 0 & 270 & 177 & 62 & 838 \\
\hline \begin{tabular}{|l|l}
4 \\
\end{tabular} & Викиди забруднюючих речовин, всього & $\mathrm{T} / \mathrm{pi \kappa}$ & 15.13 & 25090.44 & 4280.42 & \begin{tabular}{|l|}
4594.78 \\
\end{tabular} & 12658.97 & 28250.42 & 603.12 & 5655.44 & 12.79 & 103375.68 & 26843.56 & 62623.35 & 274004.10 \\
\hline 5 & в тому числі: & & & & & & & & & & & & & & \\
\hline 6 & з організованих джерел & т/рік & 10.03 & 24892.84 & 3948.90 & 4434.59 & 2290.72 & 23739.70 & 11.13 & 764.42 & 5.70 & 91350.16 & 25946.60 & 62084.21 & 239479.00 \\
\hline 7 & 3 неорганізованих джерел & т/рік & 8.87 & 197.60 & 331.51 & 160.18 & 7205.08 & 3041.83 & 591.99 & 5026.85 & 7.09 & 3615.61 & 896.96 & 539.14 & 21622.72 \\
\hline 8 & твердих & $\mathrm{T} / \mathrm{pi \kappa}$ & 0.66 & 328.34 & 444.70 & 573.90 & 619.12 & 292.84 & 41.29 & \begin{tabular}{|l|}
738.49 \\
\end{tabular} & 0.00 & 736.60 & 774.95 & 739.14 & 5290.02 \\
\hline 9 & газоподібних та рідких, всього & т/рік & 3.82 & 669.16 & 3807.10 & \begin{tabular}{|l|}
1012.87 \\
\end{tabular} & 9025.21 & 27353.67 & 549.05 & 1426.55 & 0.00 & 102913.74 & 26060.65 & 61333.35 & 234155.17 \\
\hline 10 & метан & т/рік & 0.00 & 13717.18 & 3643.94 & 0.11 & 1013.79 & 33915.32 & 0.00 & 2740.75 & 0.00 & 101005.72 & 20567.85 & 38297.66 & 214902.32 \\
\hline 11 & Використано метану, всього & млн.куб.м & 0.00 & 0.00 & 0.00 & 0.00 & 0.00 & 0.00 & 0.00 & 0.00 & 0.00 & 0.00 & 4882.93 & 14.39 & 4897.32 \\
\hline 12 & в тому числі: & & & & & & & & & & & & & & \\
\hline 13 & з викидів дегазаційних систем & млн.куб.м & 0.00 & 0.00 & 0.00 & 0.00 & 0.00 & 0.00 & 0.00 & 0.00 & 0.00 & 0.00 & 0.00 & 0.00 & 0.00 \\
\hline 14 & з викидів вентиляційних установок & млн.куб.м & 0.00 & 0.00 & 0.00 & 0.00 & 0.00 & 0.00 & 0.00 & 0.00 & 0.00 & 0.00 & 0.00 & 11.83 & 11.83 \\
\hline 15 & Викиди важких металів в атмосферу від стац.у & кг/рік & 6.80 & 122.00 & 36.00 & 114.58 & 37.34 & 192.54 & 0.00 & 225.36 & 0.00 & 1246.56 & 188.31 & 210.00 & 2379.49 \\
\hline 16 & Обсяг викидів парникових газів, всього & т./piк & 4761.25 & 16752.59 & 4294.15 & 10635.35 & 16331.24 & 70915.05 & 0.00 & 19823.65 & 0.00 & 55662.57 & 15046.41 & 43251.06 & 257473.31 \\
\hline
\end{tabular}




\section{Література}

1. Улицький О.А., Срмаков В.М., Бондар О.І. Звіт про НДР «Моніторинг виконання природоохоронних робіт та екологічного стану природного довкілля діючих та ліквідованих вугільних підприємств, розроблення пропозицій щодо його поліпшення» Э1341601000 (проміжний етап), Київ, 2018. - 51 с.

2. Кузін Ю.С. Охорона навколишнього природного середовища на підприємствах вугільної галузі. Щорічні показники природоохоронних робіт. / Ю.С. Кузін: фонди УкрНДппроект, Київ, 2010. $-28 \mathrm{c}$.

3. Г.І. Рудько Екологічна безпека вугільних родовищ України /Г.І. Рудько, О.І. Бондар, С.О. Яковлєв, О.А. Машков, С.А. Плахотній, В.М. Єрмаков: монографія. - Київ - Чернівці: Букрек, 2016. -608 c.

4. Моніторинг довкілля: підручник [для студ. вищ. навч. закл.] / [Боголюбов В.М., Клименко М.О., Мокін В.Б., Сафранов Т.А. та ін.] - 2-е вид., перероб. і доп. - Вінниця: ВНТУ, 2010. $232 \mathrm{c}$.

5. Улицкий О.А. Экологическая безопасность угольных предприятий: индикаторы жизнеспособности системы / О.А Улицкий, М.В. Кротинова // Международный научный журнал «Наука и мир». - 2014. - № 9 (13). - С. 179-183.

6. Розвиток державної системи моніторингу довкілля в Донецькій області: збірка доповідей науково-практичної конференції. - Державне підприємство «Східноукраїнський екологічний інститут». - Слов'янськ, 2015.

7. Лисиченко Г.В., Забулонов Ю.Л., Хміль Г.А. Природний техногенний та екологічний ризики: аналіз, оцінка, управління // монографія: Вид-во «ЗАТ фірма «Вітол». - Київ, 2008. $544 \mathrm{c}$.

8. Денісов Н., Аверін Д., Срмаков В. Оцінка екологічної шкоди та пріоритети відновлення довкілля на сході України / Н. Денісов, Д. Аверін, А. Ющук, О. Улицький, П. Бистров, С. Зібцев, С. Чумаченко, Ю. Набиванець // Організація з безпеки та співробітництва в Європі. - Київ, 2017. - 88 с.

9. Лисиченко Г.В., Хміль Г.А., Барбашев С.В. Методологія оцінювання екологічних ризиків. - Одеса: Астропринт, 2011. - $368 \mathrm{c}$.

10. Лисиченко Г.В., Хміль Г.А., Барбашев С.В. Забулонов Ю.Л., Тищенко Ю.С. Екологічний ризик: методологія оцінювання та управління. Навч. посібник. - К.: Наук.думка, 2014 $-328 \mathrm{c}$.

11. Верховцев В.Г. Прикладные (поисковые и инженерно-геологические) аспекты изучения платформенных геоструктур Украины // Екологія довкілля та безпека життедіяльності. 2005. - № 3. - С. 80-92.

12. Верховцев В.Г. Новейшие платформенные геоструктуры Украины и динамика их развития / Дис... д-ра геол. наук. - Киев, 2007. - 423 с.

13. Україна в цифрах: статистичний збірник. - К.: Державна служба статистики України, 2014. - 239 с.

14. Положення про Державну систему моніторингу довкілля. Постанова КМУ від 30.03.1998 р. № 391.

15. Закон України «Про охорону навколишнього природного середовища» Відомості Верховної Ради, 1991, № 41.

16. Муніципальна екологічна інформаційноаналітична система м. Києва - Електронний ресурс] https://www.arcgis.com/home/item.html?id

f0a36dff5621422594194894e2fc260b

17. Система «ОМОС» - [Електронний ресурс] http://www.ecobank.org.ua/Pages/omos.aspx

18. Нова Енергетична стратегія України до 2035 року: «Безпека, енергоефективність, конкурентоспроможність» схвалена Кабінет Міністрів України своїм розпорядженням від 18 серпня 2017 p. № 605-p.

\section{References}

1. Ulytsky O.A., Yermakov V.M., Bondar O.I. (2018), Zvit pro NDR «Monitorynh vykonannya pryrodookhoronnykh robit ta ekolohichnoho stanu pryrodnogo dovkillya diyuchykh ta likvidovanykh vugilnykh pidpryyemstv, rozroblennya propozytsiy shchodo yoho polipshennya» E 1341601000 (promizhnyy etap), Kyiv, UA, 51 p.

2. Kuzin Y.S. (2010), Okhorona navkolyshnogo pryrodnogo seredovyshcha na pidpryyemstvakh vugilnoyi haluzi. Shchorichni pokaznyky pryrodookhoronnykh robit, Fondy UkrNDIproekt, Kyiv, UA, 28 p.

3. Rudko G.I., Bondar O.I., Yakovlyev Y.O., Mashkov O.A.(2016), Ekolohichna bezpeka vuhilnykh rodovyshch Ukrainy: monohrafiya, Chernivtsi: Bukrek, Kyiv, UA, 608 p.

4. Bogolyubov V.M., Klymenko M.O., Mokin V.B., Safranov T.A. (2010), Monitoryng dovkillya: pidruchnyk, Vinnytsya: VNTU, UA, $232 \mathrm{p}$.

5. Ulitskiy O.A. (2014), Ekologicheskaya bezopasnost ugolnykh predpriyatiy: indikatory zhiznesposobnosti sistemy, Mezhdunarodnyy nauchnyy zhurnal «Nauka i mir», № 9 (13), RU, pp. 179-183.

6. Rozvytok derzhavnoyi systemy monitoryngu dovkillya v Donetskiy oblasti: zbirka dopovidey naukovo-praktychnoyi konferentsiyi (2015), Derzhavne pidpryyemstvo «Skhidnoukrayinskyy ekolohichnyy instytut», Slovyans'k, UA.

7. Lysychenko G.V., Zabulonov YU.L., Khmil G.A. (2008), Pryrodnyy tekhnogennyy ta ekolohichnyy ryzyky: analiz, otsinka, upravlinnya: monohrafiya, Vyd-vo «ZAT firma «Vitol»., Kyiv, UA, $544 \mathrm{p}$.

8. Denisov N., Averin D., Yermakov V. (2017), Otsinka ekologichnoyi shkody ta priorytety vidnovlennya dovkillya na skhodi Ukrainy, Orhanizatsiya z bezpeky ta spivrobitnytstva v Yevropi, Kyiv, $\mathrm{UA}, 88 \mathrm{p}$.

9. Lysychenko G.V., Khmil G.A., Barbashev S.V. (2011), Metodologiya otsinyuvannya ekologichnykh ryzykiv, Odesa: Astroprynt, UA, 368 p.

10. Lysychenko G.V., Khmil G.A., Barbashev S.V. Zabulonov Y.L., Tyshchenko Y.E. (2014), Ekologichnyy ryzyk: metodologiya otsinyuvannya ta upravlinnya. Navch. Posibnyk, K.: Nauk. dumka, UA, 328 p.

11. Verkhovtsev V.G. (2005), Prykladnye (poyskovye y ynzhenerno-heolohycheskye) aspekty izuchenyya platformennykh geostruktur Ukrainy, Ekologiya dovkillya ta bezpeka zhyttyediyalnosti № 3 , RU, pp. 80-92.

12. Verkhovtsev V.G. (2007), Noveyshiye platformennyye geostruktury Ukrainy i dinamika ikh razvitiya, Dis.D. Sc. (Geol.), Kiev, RU, $423 \mathrm{p}$

13. Ukraina v tsyfrakh: statystychnyy zbirnyk (2014), Derzhavna sluzhba statystyky Ukrainy, UA, 239 p.

14. Polozhennya pro Derzhavnu systemu monitorynhu dovkillya. Postanova KMU vid 30.03.1998 № 391, UA.

15. Zakon Ukrainy «Pro okhoronu navkolyshnogo pryrodnogo seredovyshcha» Vidomosti Verkhovnoyi Rady, 1991, № 41, UA.

16. Munitsypalna ekolohichna informatsiyno-analitychna systema m. Kyeva, available at:https://www.arcgis.com/home/item.html?id= f0a36dff5621422594194894e2fc260b

17. Systema «OMOS»,

available at:http://www.ecobank.org.ua/Pages/omos.aspx

18. Nova Enerhetychna strategiya Ukrayiny do 2035 roku: «Bezpeka, enerhoefektyvnist, konkurentospromozhnist» skhvalena Kabinetom Ministriv Ukrainy svoyim rozporyadzhennyam vid 18.08.2017, № 605-r, UA. 
ТЕХНОГЕННОЕ ЗАГРЯЗНЕНИЕ АТМОСФЕРЫ В РЕЗУЛЬТАТЕ ФУНКЦИОНИРОВАНИЯ И ЗАКРЫТИЯ УГОЛЬНЫХ ШАХТ И МЕРЫ ПО ЕГО ПРЕДОТВРАЩЕНИЮ (МИНИМИЗАЦИИ)

Буглак А.В., м.н.с. Государственная экологическая академия последипломного образования и управления, aleksandra.verkhovtseva@gmail.com.

Добыча угля приводит к изменениям окружающего ландшафта за счет накопления горных масс. Шахтные породы в терриконах склонны к самовозгоранию, что приводит к химическому загрязнению атмосферы продуктами горения. Рассмотрены особенности нарушений окружающей среды и последствия, обусловливающие загрязнения атмосферного воздуха. Установлены основные проблемы охраны атмосферного воздуха, к которым относятся выявление фактических выбросов вредных веществ в атмосферу по технологическим циклам, объектами шахтного комплекса и угольными предприятиями в целом, проведение их количественной и качественной оценки.

Проанализированы и графически проиллюстрированы данные по загрязнению атмосферного воздуха угольными предприятиями Украинь за 2018. В качестве природоохранных мероприятий по атмосферному воздуху предлагается и предусматривается: проведение работ по тушению породных отвалов; применение экологически чистых и безопасных технологий формирования новых породных отвалов; выполнение профилактических работ по предотвращению самовозгорания отвалов; оснащение организованных источников выбросов новыми газоочистными установками, аспирационными системами, золоуловителями, электрофильтрами; реконструкция котлоагрегатов котельных и тому подобное.

Ключевые слова: угольная шахта, окружающая среда, техногенное загрязнение, атмосферный воздух, эколого-технические показатели, природоохранные мероприятия, база данных.

\section{TECHNOGENIC POLLUTION OF ATMOSPHERE AS A RESULT OF FUNCTIONING AND CLOSING OF COAL MINES AND MEASURES TO PREVENT IT (MINIMIZATION)}

O. Buglak,Research Assistant, State Ecology Academy of postgraduate education and management, aleksandra.verkhovtseva@ gmail.com

Coal mining leads to changes in the surrounding landscape due to the accumulation of rock masses. Mine rocks in the heaps are prone to spontaneous combustion, which leads to chemical pollution of the atmosphere by combustion products. The features of environmental disturbances, their causes (in particular, emissions of poisonous substances by industrial enterprises of the region, emissions of greenhouse gases and solid particles (soot) from chimneys, evaporation of volatile toxic substances from settling tanks, dust pollution - blasting of poisonous substances from the ash, slag and slurry ditches, waste hens, atmospheric pollution air emissions from stationary and mobile sources - ash from thermal power plants, formaldehyde, nitrogen dioxide, etc., cross-border transfer of pollutants into the air in border areas, etc.) and the consequences of air pollution are considered. The main problems of atmospheric air protection are identified, which include the identification of actual emissions of harmful substances into the atmosphere through technological cycles, facilities of the mine complex and coal enterprises in general, their quantitative and qualitative assessment. The data on atmospheric air pollution by coal enterprises of Ukraine for 2018 are analyzed and graphically illustrated. As environmental measures for atmospheric air, it is proposed and foreseen: work to extinguish waste dumps; the use of environmentally friendly and safe technologies for the formation of new waste dumps; perform preventive work to prevent spontaneous ignition dumps; equipping organized emission sources with new gas treatment plants, aspiration systems, dust collectors, electrostatic precipitators; reconstruction of boilers etc.

Key words: coal mine, environment, technogenic pollution, atmospheric air, ecological and technical indicators, environmental measures, database. 